\title{
URBAN POVERTY AND “THE RIGHT TO CULTIVATE THE EARTH": AMERICAN LAND REFORMERS IN THE 1840s
}

Eric Fure-Slocum

Late twentieth-century disputes about welfare reform hinge on differing notions of poverty and dependency. Dubbing their recent welfare reform proposal "The Personal Responsibility Act," Republican Party leaders contend that welfare fosters personal dependency and aggravates poverty. Critics, however, point to the paucity of the welfare state itself, charging that it is inadequate in both size and scope to meet the challenges of poverty and social inequality. ${ }^{1}$

Likewise, in the mid-nineteenth century a wide range of reformers, public officials, and others debated the causes and results of poverty. The American land reformers of the 1840s, an eclectic movement of radical artisans, mechanics, and union activists championing the "right to cultivate the earth," were especially alarmed about the dangers posed by urban poverty. ${ }^{2}$ But unlike many middle-class reformers of the time who viewed the urban poor as the "dangerous classes," the land reformers saw impoverished urbanites as both an endangered class and a sign of the endangered republic. Struggling to reconcile these observations of the troubled city and the changing workplace with their conception of the republic, the land reformers articulated a working-class vision of antebellum reform.

Nurtured in the environs of New York City, this land reform movement emerged in the early 1840s largely through the initiatives of George Henry Evans. Born in England, a printer by trade and a freethinker by disposition, Evans played an active role in New York's early workers' movement. ${ }^{3} \mathrm{He}$ began publishing The Working Man's Advocate in 1829 and continued until 1836, when poor health and financial difficulties forced him to retire to the countryside. In 1841, Evans introduced The Radical, a monthly in which he reassessed the workers' movement of the 1830s and developed his reform proposals. Then in 1844, Evans returned to New York City and, with John Windt, initiated a new series of The Working Man's Advocate. ${ }^{4}$ Along with a small group of radical 
artisans and mechanics, Evans also helped found the National Reform Association, an organization dedicated to the crusade for land reform.

Particularly distressed by the destitution in the burgeoning metropolis, the National Reformers were committed to land reform as the foremost correction for society. They both argued that "surplus labor" drove down urban workers' wages and attacked the "Land Monopoly" as the enemy of the republic. Building on their experience in the Working Men's party, the Loco-Focos, and the Democratic party, the land reformers sought a political solution to the nation's ills. They enunciated the principle of the "Natural Right to Land" and called for access to the public lands by actual settlers only, strict acreage limitations, and exemptions to prevent homesteads from being seized by creditors. ${ }^{5}$ In The Radical, The Working Man's Advocate, The People's Rights, and Young America!, Evans and the other reformers tried to understand the causes and the extent of poverty in the city, as well as the place of poverty in their conceptions of the republic and democracy.

New York City in the 1840s was a growing commercial, financial, and manufacturing center. But it was also home to a growing number of "unskilled" workers, who suffered from high rates of unemployment, falling wages, and seasonal downturns in the winter months. The depression of the late 1830s and the early 1840 s, the sharp increase in the number of immigrants settling in the city during the latter part of the decade, and the continuing workplace changes fostered by the spread of industrial capitalism, made for volatile and often desperate social conditions in New York City. ${ }^{6}$ Though the full extent of the despair in the 1840 s is impossible to pinpoint, the many stories of privation recounted by reformers, journalists, travelers, and public officials indicate that urban poverty was perceived as a central dilemma for antebellum society. ${ }^{7}$

George Henry Evans and the land reformers regularly pointed to increased penury in the metropolis. Commenting on the city's rapid growth and accumulating poverty, Evans asserted: "Never in the world's history were the poor driven more rapidly to the starvation point than the poor in the U.S. have been for the last ten years."8 $\mathrm{He}$ observed the widening disparity between the city's wealthy and poor residents and he noted that, while beggars were encountered regularly in the early 1840 s, they rarely had been seen in the city twenty years earlier. ${ }^{9}$ For Evans, then, rapid growth did not mean urban progress, and his eight years' absence from the city (1936-1944) gave him a chance for reflection:

I was away eight years...but when I came...to survey the "improvements," as they are termed, on my return, my astonishment was indescribable;... [though] I am becoming somewhat familiar with the city's rapid growth, I cannot visit its environs without being immensely puzzled to know how the garrets, cellars, and back buildings can possibly contain human beings enough to have done all the building that I see. ${ }^{10}$

The crowding and poverty in the garrets and cellars demanded examination. 
To explain the presence of poverty, the land reformers first attempted to refute commonly held perceptions. Evans challenged the eighteenth-century notion that poverty was woven into the fabric of the world. "It is wrong to say that God made Rich and Poor; he made only Male and Female; and he gave them the earth for their inheritance."11 More frequently, though, the land reformers attacked the prevailing mid-nineteenth century conception of poverty. In response to a speech by New York's Mayor James Harper, the Advocate pointed to the city's hard-pressed workers and stated emphatically: "can the new Mayor be serious when he asserts that 'in this country, as a general rule, the MEET REWARD of industry is SURE?"' Contrary to the claims that intemperance creates "vice, poverty, crime, and misery," the land reformers charged that "Poverty is the most fruitful source of intemperance, vice, crime, misery." 12 Further, Evans and his allies questioned the conventional association between poverty, the lower classes, and criminality, noting wryly: "The man in whom no trust is placed, that steals a pair of breeches or brogans, is a felon. He in whom unbounded confidence is placed, that steals thousands in dollars, is only a defaulter."13

The land reformers emphasized that the growing inequities and the spreading poverty in the nation and the city were the result of two interrelated forces: land monopoly and labor surplus. The land monopoly, however, stood as the first corruption. As Evans stated in the first issue of The Radical: "The truth is that the monopoly of the land is the cause of your oppression, the cause why labor is rewarded in an inverse ratio to its usefulness." 14 This monopoly on the control of land paved the way for exploitation and misery in the city because the soil no longer offered an outlet for the rapidly expanding population.

The resulting surplus of labor in the city drove down wages "to the starvation point," making the factory and wage systems instruments of urban decline. Evans stated bluntly, "I cannot see how the landless poor are to benefit by a system that will consign their children to a fate worse than Russian serfdom." 15 Descriptions of factory life in the land reformers' newspapers were punctuated with warnings of poverty and encumbrance. ${ }^{16}$ The labor surplus also prevented workers from organizing effectively to raise wages or oppose changes in working conditions. ${ }^{17}$ For instance, nativist riots (which Evans strongly condemned) reflected the workers' inability to identify and organize around their central problem. Evans insisted that native workers should seek access to the "abundance of land," rather than challenge the rights of immigrants. ${ }^{18}$ The surplus generated by the monopoly, then, threatened all producers in the city, degrading all aspects of urban life and work.

Evans and his associates frequently employed depictions of British and European industrialization to highlight the dangers of urban poverty and dependence. Evans wrote that the "British cities are but vast receptacles of human suffering." 19 The American Republic, he believed, should offer a contrast to and escape from old world "despotisms." Rather than falling to the position of a "degraded tenantry," American workers should become "independent freemen." ${ }^{20}$ But the land monopoly was undermining this hope. "Such is the British 
System, a system founded on the monopoly of the land by the few. Such, inevitably, would be the American System, were the land to continue a matter of merchandise." 21

Images of impoverished women in the city also appeared frequently in the National Reformers' newspapers. Hungry widows, overworked seamstresses, debased domestic servants, and forlorn prostitutes attested to the evils of the wage and factory systems and the far-reaching impact of the land monopoly. ${ }^{22}$ Without reform, the future that Evans foresaw for working women crowded into the city was grim: "you will be then...reduced to the extremity of the females of London who make shirts for a penny a day, and frequently die in a landlord's garret of actual starvation." 23 Evans and his associates, sharing in the republican or "radical paternalism" of the mid-nineteenth-century labor movement, called for the protection of women with a return to the household economy. 24

If your fathers, husbands, or brothers had each possessed their inalienable right to land enough to live upon, and each had their own houses instead of being crowded together in other people's houses in this city, many thousands of you [working women] would now have been under your fathers' roofs, the happy and independent mistresses of your own households, with your vines, your flowers, your gardens, and your orchards. ${ }^{25}$

Women's oppression and poverty in the city, the land reformers believed, largely followed from male workers' dependence on wage-labor. The solutions they offered, which sought both to break the land monopoly and to drain the pool of surplus labor in the cities, entailed primarily a restoration of working men's independence. And despite some ambivalence, working-class women were largely expected to remain dependent. However, the land reformers prescribed that women's dependency should be based in the republican household, instead of on the factory floor or in the garret dwelling. Women were to be dependent on husbands or fathers, not bosses or landlords. ${ }^{26}$

To build support for their campaign, the land reformers tried to enlist the help of working-class women. Appealing to women as Republican Mothers, The Working Man's Advocate urged them to "coax" their sons and husbands to join the National Reform effort. Though the reformers eventually extended an invitation to women to attend the National Reform Association meetings, they did not envision women as full and equal participants in either the movement for reform or the reformed society. ${ }^{27}$

Turning their lens to the American South, the land reformers further shaped their perceptions of poverty and dependence through comparisons between slavery and "free labor." While supporting abolition, Evans criticized abolitionists for ignoring the plight of the Northern worker. To exert moral influence over slave owners, the abolitionists had to account for the "white 
slavery" of the Northern states, he argued. ${ }^{28}$ In a fictional dialogue printed in The Working Man's Advocate, a Southerner chastised an Abolitionist for disregarding the "mental and physical suffering among the laboring poor in the city of New York." 29 Further, the Southerner complained that the advocates of emancipation neglected the slaves' material well-being. "What! Turn him loose upon the highway with the privilege only to wander up and down upon it as a vagabond."30 Though the irony of the Southerner's concern for the slave was not to be missed by the readers, the wage-labor system also came under attack.

In 1844, The Working Man's Advocate featured the correspondence between Evans and the abolitionist Gerrit Smith. ${ }^{31}$ In this forum, Evans sharpened his distinction between poverty and dependence. He wrote: "I do not assert that poverty makes a man a slave; for a man might be poor and yet be independent... The man who has no land and therefore must work for others, is the slave, whether he has one master or the choice of many." 32 Likening the wage system and slavery, Evans contrasted both to his ideal of independence. However, this logic_-while possibly effective in persuading Northern workers and abolitionists of the wage system's faults-severely compromised Evans' condemnation of the unique inhumanity of the Southern slave system. ${ }^{33}$

Dependence, then, was the great danger confronting urban workers and the Republic. The Working Man's Advocate warned against complacency in the face of this danger:

Men of New York, here is the serfage that is in store for your unhappy children....If, recreant to manhood, you are content to paternize a race of slaves, ask not the spotless daughters of America to share your dishonor. Perish unborn your offspring. ${ }^{34}$

Contrasting the American worker to the industrial worker and serf of Europe, distinguishing the white worker from the slave in the South, and situating the male worker over his female relations, the land reformers forged their notion of the republican worker. ${ }^{35}$ Evans and the land reformers believed that a poor but independent farmer lived a better life than a materially comfortable but encumbered worker. For the latter was in a fragile position. In the volatile urban economy of the mid-nineteenth century, the dependence inherent in the wage system denied workers the means to prevent destitution. But, as noted earlier, the land reformers' wrath was not directed at the wage system alone. Rather, the swelling labor surplus and, most importantly, the entrenched land monopoly combined to make the wage system a trap of dependence.

Further, this dependence endangered both economic and political freedom. Sounding an egalitarian critique of the emerging industrial capitalism, Evans and his allies articulated an alternative conception of the relationship between suffrage and independence, between political rights and economic rights. For the land reformers, the daily sight of urban poverty, and the dependence that implied, made manifest the erosion of republican independence. 
The bondage and social turmoil that the land reformers focused on contrasted with the type of dependence that many other antebellum reformers associated with poverty. For the land reformers, dependence had distinctly social roots; charges of individual moral failure were absent. While middle- and upperclass reformers may have pointed to social factors-such as the breakdown of order and social hierarchy - as partial causes of pauperism, they regularly blamed the poor themselves for individual (or familial) depravity and dependence. ${ }^{36}$

The National Reformers' critiques of other urban reformers drew out this distinction, particularly evident in their arguments against work houses and their assaults on the ideology of "charity." Surveying the spread of poverty in the city, The Working Man's Advocate denounced the inadequacy of public relief efforts. "These insolent officials...dole out the paltry pittance of the poor widow or destitute orphan as if it was a charity instead of a right, that the poor apply for." Even more reprehensible were proposals for a work house, which Evans described as a denial of "all the rights of humanity" to paupers and, consequently, an infringement on the liberty of all. ${ }^{37}$

The land reformers also scorned many of the private charity efforts directed at impoverished New Yorkers. ${ }^{38}$ Evans ridiculed the Association for the Relief of the Poor for their efforts to teach paupers the values of "frugality, temperance, industry and self-dependence."

\begin{abstract}
Preach "frugality" to a beggar! "Temperance" to a wretch who has lost all hope of the means of any enjoyment in life except from the momentary gratification of his appetites! "Industry" to those who in vain have begged leave to toil! "Self-dependence" to a starving family, whom a landlord is harassing for his rent. $\mathrm{O}$ for the end of this age of mock-philanthropy and humbugs! 39
\end{abstract}

Convinced that the causes of penury were beyond the realm of individual moral failure, the land reformers believed that the middle-class reformers' efforts were senseless.

Evans also aimed his sarcasm at the innovators of "scientific charity," a form of philanthropy that organizations such as the New York Association for Improving the Condition of the Poor promoted in the 1840s. In one column, Evans described stories that had appeared in the True Sun about a fourteen-yearold girl who had "deceived" a wealthy patron into assisting her distressed parents and of a woman who had stolen "ninepence worth of wood to help her sick children." 40 While for the original tellers such stories may have suggested the need for "a systematic and uncompromisingly realistic application of the methods prescribed by "modern philanthropy," for Evans these tales underscored the degree to which thousands of New Yorkers had been impoverished and deprived of their rights or dignity. ${ }^{41}$

In their prescriptions for change, the land reformers placed the ideal of 
republican independence at the center. The bondage of contemporary society, symbolized daily by urban poverty, contrasted to their understanding of the nation's republican heritage and mission. Their proposal for equal rights in access to the land established the means by which republican independence could be salvaged.

[The] equal right to land would create the proper equilibrium between the agricultural and other occupations, leaving a surplus of neither, and no man dependent on another for the right to work for a living, or with power to extort the labor of others without equivalent. 42

By breaking the land monopoly and draining off the labor surplus, republican values would thrive.

The National Reformers' plan for dividing up the public lands into sixmile-square townships, in which land was understood to be a natural and inalienable right, constituted their mechanism for reforming society as a whole. This was not a plan promoting individual homesteading or speculation on the isolated frontier, but instead a strategy for building communities.

If the public lands were made free to actual settlers,... so that settlers might locate themselves near a market, or form markets among themselves, the surplus mechanics and other laborers of the present unjust and unnatural system might become independent cultivators of the soil, capable of adding to the national wealth. ${ }^{43}$

The land reformers declared that this plan offered society the prospect of cultivating responsible citizens rather than "paupers or criminals by compulsion." 44 Stressing the urgency of these reforms, Evans and his associates promoted their political agenda as a way to redeem and stabilize urban society and stem the possibility of violent uprisings, by reversing the loss of republican independence. ${ }^{45}$ The National Reformers' proposal for the establishment of sixmile-square townships contained both an egalitarian critique of industrial capitalism, seriously compromised by the limits of their call for racial or gender equality, and a plan for social regeneration that would lay the communal foundations for republican independence.

In their critique of industrial capitalism, their analysis of urban poverty, and their efforts to rescue republican independence, the land reformers articulated a working-class alternative to the middle-class reform ideologies of the mid-nineteenth century. Like the shoemakers of Lynn, Massachusetts who, in their dread of dependency, "combined the currents of moral reform and an emerging working-class consciousness," the National Reformers analyzed urban poverty, as well as the urban and national crises more generally, within the context of a republicanism that was shaped and reshaped by workers in the 
changing metropolis. ${ }^{46}$

But the land reformers' working-class ideology was not wholly distinct from other currents of antebellum reform. They shared in the "romantic perfectionism" that imbued much of antebellum reform, believing that salvation was available to all people and all of society. ${ }^{47}$ Though the land reformers insisted that social regeneration preceded individual rejuvenation, thereby reversing the sequence implied by the tenets of perfectionist individualism, they too believed that complete salvation could be attained. Evans articulated this in his call for a comprehensive reform of public lands policy:

Yes; the time must come, is coming, when the present odious distinctions of rich and poor, landlords and landless, shall be banished from the earth; when every man shall get his living by honest toil, and when every family shall sit under their own vine, with none to make them afraid. 48

All of society and each individual could be transformed. And despite their many condemnations of the nation's and the city's wealthiest members, the land reformers asserted that their proposals should appeal to rich and poor alike. All would gain as good displaced the evil in society. The land reformers, then, shared with other antebellum reformers the profound belief that salvation and reconciliation were soon attainable. ${ }^{49}$

Yet the striking dissimilarity between the land reformers' and middleclass reformers' explications of urban poverty and dependence argues against an interpretation that seeks to fit all antebellum reformers into a single mold. Grappling with their evidence of antebellum urban poverty and dependence, the land reformers both articulated a distinctive working-class ideology and joined with middle-class reformers in a crusade for salvation. In their surveys and interpretations of urban poverty and dependence, in descriptions of deteriorating conditions for workers, in reflections on the British and European experiences, in deliberations about the plight of women in the city, in contrasts of wage labor and Southern slavery, in critiques of middle-class reform efforts, and in their embracing of romantic perfectionism, the land reformers can be seen as fully engaged in the complex world of antebellum reform. Further, by recognizing the land reformers as full participants in this movement, antebellum reform itself can be better understood for its complexity and multiplicity, rather than being viewed as a single phenomenon.

Recounting a recent stroll in New York, George Henry Evans exclaimed that he had chanced upon an area with open yards and vegetation, an almost pastoral scene in the city. He quipped:

What are our capitalists thinking about, to allow these back yards thus to remain unproductive? Are they aware of the tendency of these flowers, grape vines, and grass plats, to 
perpetuate silly notions among the "lower orders," about the use of the earth? The sooner all traces of vegetation are eradicated from our thriving metropolis, the better it will be for the security of property. 50

Championing "the right to cultivate the earth," Evans and the land reformers strove not only to create a balance between the land and the city, but hoped and expected to eradicate urban poverty and revive the independent republic.

\section{Notes}

I wish to thank Barbara Loomis, Allen Steinberg, Shel Stromquist, Carolyn Fure-Slocum, and this journal's editors for their valuable suggestions. An earlier version of this article was presented at the 19th Annual Communal Studies Conference in Nauvoo, Illinois, on October 17, 1992.

${ }^{1}$ See Nancy Fraser and Linda Gordon, “'Dependency' Demystified: Inscriptions of Power in a Keyword of the Welfare State," Social Politics 1 (1994): 4-31; Linda Gordon, "Welfare Reform: A History Lesson," Dissent 41 (1994): 323-328; Michael B. Katz, The Undeserving Poor: From the War on Poverty to the War on Welfare (New York: Pantheon Books, 1989); and Barbara Vobejda, "Cutting Through Welfare Reform on the Way to Personal Responsibility," Washington Post National Weekly Edition, 19-25 December 1994, 8.

${ }^{2}$ Presenting a vivid picture of the new republic's failures and possibilities, land reform leader George Henry Evans wrote in 1841: “[a] century hence it will be matter of special wonder that, half a century after the foundation of the republic the many were still dependent on the few for the right to cultivate the earth." The Radical June 1841: 84.

${ }^{3}$ For discussions of Evans and his work, see Helene S. Zahler, Eastern Workingmen and National Land Policy, 1829-1862 (New York: Columbia UP, 1941); Sean Wilentz, Chants Democratic: New York City and the Rise of the American Working Class, 17881850 (New York: Oxford UP, 1984); Paul K. Conkin, Prophets of Prosperity: America's First Political Economists (Bloomington: Indiana UP, 1980); and Arthur M. Schlesinger, Jr., The Age of Jackson (Boston: Little, Brown and Company, 1945). Also see Evans' brother's autobiography, Frederick W. Evans, Autobiography of a Shaker and the Revelation of the Apocalypse (Glasgow: United Publishing Co., 1888; reprint, Philadelphia: Porcupine Press, Inc., 1972). On freethought and labor activists, see Mark A. Lause, "The 'Unwashed Infidelity': Thomas Paine and Early New York City Labor History," Labor History 27 (1986): 385-409; and Sean Wilentz, Chants Democratic, 153-157.

${ }^{4}$ For a brief history of these labor papers, see C.K. McFarland and Robert L. Thistlethwaite, "20 Years of a Successful Labor Paper: The Working Man's Advocate, 1829-49," Journalism Quarterly 60 (1983): 35-40. Evans and his associates also subsequently published The People's Rights, The Subterranean and Working Man's Advocate, and Young America!. These papers, along with The Radical and The Working Man's Advocate, are available on microfilm in The American Periodical Series, 1800-1850. 
${ }^{5}$ The Working Man's Advocate, 18 May 1844, 1. A number of historians argue that the National Reformers played an important role in the development of land policy and working-class or radical politics (especially in holding together a radical organization through the 1840s). See Zahler, Eastern Workingmen; Wilentz, Chants Democratic; Mark A. Lause, "The American Radicals and Organized Marxism: The Initial Experience, 1869-1874," Labor History 33 (1992): 55-80; and Lause, "Voting Yourself a Farm in Antebellum Iowa: Towards an Urban, Working-Class Prehistory of the Post-Civil War Agrarian Insurgency," Annals of Iowa 49 (1988): 169-186.

${ }^{6}$ Edward K. Spann, The New Metropolis: New York City, 1840-1857 (New York: Columbia UP, 1981) 71-72. By one estimate, in 1855 about two-thirds of New York's labor force "worked at essentially unskilled jobs." Diane Lindstrom, "Economic Structure, Demographic Change, and Income Inequality in Antebellum New York," Power, Culture, and Place: Essays on New York City, ed. John Hull Mollenkopf (New York: Russell Sage Foundation, 1988) 11. Female workers and recent immigrants, as well as native workers, filled these positions. See Christine Stansell, City of Women: Sex and Class in New York, 1789-1860 (New York: Alfred A. Knopf, 1986; reprint, Urbana: U of Illinois P, 1987); and Wilentz, Chants Democratic. Due to the availability of sources, this essay focuses on the first half of the 1840s. On the second half of the 1840s and the 1850s, see Richard B. Stott, Workers in the Metropolis: Class, Ethnicity, and Youth in Antebellum New York City (Ithaca: Cornell UP, 1990).

${ }^{7}$ Based on relief cases, The Working Man's Advocate asserted that 51,600 paupers lived in New York City in 1843 (approximately one-seventh to one-sixth of the population). That number, they stated, rose to 55,000 in 1844. "Pauperism and the Remedy," The Working Man's Advocate, 8 February 1845, 2. Also see "The Mayor's SpeechPauperism and Intemperance," The Working Man's Advocate, 18 May 1844, 2; and The Working Man's Advocate, 11 May 1844, 3. On reports and perceptions of urban poverty, see Stansell, City of Women; Paul Boyer, Urban Masses and Moral Order in America, 1820-1920 (Cambridge: Harvard UP, 1978); and David Ward, Poverty, Ethnicity, and the American City, 1840-1925: Changing Conceptions of the Slum and the Ghetto (New York: Cambridge UP, 1989).

8"Rich and Poor," The Subterranean and Working Man's Advocate, 16 November 1844, 2.

${ }^{9}$ At the same time, prisons and poor houses were expanding. See The Radical November 1841: 163; and The Radical January 1841: 1, 8.

10“Rich and Poor," 2.

11 "Rich and Poor," 2.

${ }^{12}$ The Working Man's Advocate, 18 May 1844, 2. Also see The Radical March 1841: 37.

${ }^{13}$ The Radical, 1 (December 1841), 190. The land reformers disdained the "swindling bank managers," who they held responsible for bank failures that impoverished widows and orphans. The Radical October 1841: 155-156.

${ }^{14}$ The Radical January 1841: 6. 
15“The Factory System," Young America! 31 May 1845, 2. Also see Orestes E. Brownson, “The Slavery of Poverty," The Working Man's Advocate, 4 May 1844, 2.

${ }^{16}$ For instance see, "White Slavery," The Radical March 1841: 37.

${ }^{17}$ The Radical January 1841: 6.

${ }^{18}$ Young America!, 19 July 1845, 2. Also see "Riots in Philadelphia," The Working Man's Advocate, 11 May 1844, 2-3.

19،The British System," The Radical December 1841: 187.

${ }^{20}$ The Working Man's Advocate, 11 May 1844, 3.

21 "The British System," 188. Also see "Present State of England, the Country of Land Monopoly," The Working Man's Advocate, 6 April 1844, 4; "Glance at the History of Land Monopoly in the British Islands," The Working Man's Advocate, 8 June 1844, 2; "Serfage in Europe," The Working Man's Advocate, 15 June 1844, 1; "The Poor of England," The Subterranean and Working Man's Advocate, 16 November 1844, 1; and "British Pauperism," Young America! 12 July 1845, 1. Some of these were reprints from British newspapers.

${ }^{22}$ See "The Poor Seamstress," The People's Rights, 17 August 1844, 3; "Freedom of the Public Lands, or Scenes in Gotham 1845 and 1850," The Working Man's Advocate, 1 March 1845, 4; "Labor in New York-The Huckster Women," Young America!, 15 November 1845, 4; and "Labor in New York-Domestic Servitude," Young America!, 24 January 1846,4 .

23“"To the Working Women of New York," The Working Man's Advocate, 15 March $1845,2$.

${ }^{24}$ See Christine Stansell, City of Women, 130-154. On the household economy, see Jeanne Boydston, Home and Work: Housework, Wages, and the Ideology of Labor in the Early Republic (New York: Oxford UP, 1990).

25“To the Working Women of New York," 2.

${ }^{26}$ On the multiple and changing uses of "dependency," see Fraser and Gordon, “"Dependency' Demystified." On the use of spatial metaphors in women's history, see Linda K. Kerber, "Separate Spheres, Female Worlds, Woman's Place: The Rhetoric of Women's History," Journal of American History 75(1988): 9-39.

27“Working Women," The Working Man's Advocate, 11 May 1844, 1; and The Working Man's Advocate, 10 August 1844, 1. On Republican Motherhood, see Linda K. Kerber, Women of the Republic: Intellect and Ideology in Revolutionary America, 2nd ed. (New York: W.W. Norton, 1986).

28“White Slavery,” The Radical March 1841: 33-38.

29“'Dialogue on Free and Slave Labor," The Working Man's Advocate, 8 June 1844, 4. The 
"fictional dialogue" format was used frequently in these papers. On the slave and free labor debate, see Jonathan A. Glickstein, “'Poverty is Not Slavery': American Abolitionists and the Competitive Labor Market," in Antislavery Reconsidered: New Perspectives on the Abolitionists, ed. Lewis Perry and Michael Fellman (Baton Rouge: Louisiana State UP, 1979) 195-218.

30"Dialogue on Free and Slave Labor," 4.

${ }^{31}$ See the following issues of The Working Man's Advocate: 6 July 1844, 3; 20 July 1844, 4; 10 August 1844, 4; 17 August 1844, 1. Also see The People's Rights, 24 July 1844, 2. Smith argued for the primacy of the antislavery cause, though over the course of their exchange Smith, a large land-holder in upper New York state, became an advocate of land reform. See Whitney R. Cross, The Burned-Over District: The Social and Intellectual History of Enthusiastic Religion in Western New York, 1800-1850 (Ithaca: Cornell UP, 1950) 327; and Conkin, Prophets of Prosperity, 250.

${ }^{32}$ The Working Man's Advocate, 17 August 1844, 1.

${ }^{33}$ See David R. Roediger, The Wages of Whiteness: Race and the Making of the American Working Class (New York: Verso, 1991) 77-80. As Roediger notes: “There was no room for oppression in Evans's world, but also no room for consideration of the special nature of the oppression of those victimized differently than his white constituency" (80).

${ }^{34}$ The Working Man's Advocate, 22 June 1844, 2.

${ }^{35}$ Helpful for this analysis is Carroll Smith-Rosenberg's "Dis-Covering the Subject of the 'Great Constitutional Discussion,' 1786-1789," Journal of American History 79 (1992): 841-873.

${ }^{36}$ See David J. Rothman, The Discovery of the Asylum: Social Order and Disorder in the New Republic (Glenview, IL: Scott, Foresman and Company, 1971) 155-179; Boyer, Urban Masses and Moral Order; Michael B. Katz, In the Shadow of the Poorhouse: A Social History of Welfare in America (New York: Basic Books, 1986); Carroll Smith Rosenberg, Religion and the Rise of the City: The New York City Mission Movement, 1812-1870 (Ithaca: Cornell UP, 1971); and Stansell, City of Women. The 1840s witnessed a resurgence of middle-class benevolent efforts.

37"The Mayor's Speech-Pauperism and Intemperance," 2. Proposals to reduce the public relief budget, which gained wider support in the mid-1840s, moved in exactly the wrong direction, they argued.

${ }^{38}$ Evans did, however, praise the work of Matthew Carey. See The Radical March 1841: 34.

39"The Rights of the Poor," The Subterranean and Working Man's Advocate, 14 December 1844, 2. Also see, "Relief of the Poor, and Response," The Working Man's Advocate, 4 January 1844, 1; and "Republican Pauperism," Young America! 20 December 1844,3 .

40"Take Care of the Rich," The Subterranean and Working Man's Advocate, 7 December 
1844, 2. Also see "Take Care of the Rich," Young America! 12 April 1845, 3.

${ }^{41}$ Smith Rosenberg, Religion and the Rise of the American City, 250. Also see The Working Man's Advocate, 25 January 1845, 2.

${ }^{42}$ The Radical June 1841: 85.

43“"Equal Right to Land," The Working Man's Advocate, 16 March 1844, 3.

44 “Equal Right to Land," 3.

${ }^{45}$ Also see, The Radical January 1841: 3; The Radical March 1841: 37; The Working Man's Advocate, 18 May 1844, 2.

${ }^{46}$ On the "rebel mechanics," see Paul Faler, "Cultural Aspects of the Industrial Revolution: Lynn Massachusetts, Shoemakers and Industrial Morality, 1826-1860," Labor History 15 (1974): 392. On the debate over working-class republicanism, see Wilentz, "Against Exceptionalism: Class Consciousness and the American Labor Movement, 1790-1920," International Labor and Working Class History 26 (1984): 1-24; and Nick Salvatore, "Response to Sean Wilentz, 'Against Exceptionalism and the American Labor Movement, 1790-1920,'” International Labor and Working Class History 26 (1984), 25 30. For an important corrective, see David Montgomery, Citizen Worker: The Experience of Workers in the United States With Democracy and the Free Market During the Nineteenth Century (New York: Cambridge UP, 1993).

${ }^{47}$ Especially see, John L. Thomas, "Romantic Reform in America, 1815-1865," American Quarterly 17 (1965): 656-681; and Cross, Burned-Over District. As a rejection of determinism, nineteenth-century perfectionism blended with secular thought to reinforce the anti-institutionalism of Jacksonian democracy and "[changed] an Enlightenment doctrine of progress into a dynamic principle of reform." Thomas, 659.

${ }^{48}$ The Subterranean and Working Man's Advocate, 14 December 1844, 1. Also see The Radical January 1842: 1-2. Further, National Reformers argued that land reform in the United States could lead to reforms in England and the rest of the world, uprooting the old world “despotisms." See The Working Man's Advocate, 11 May 1844, 3.

${ }^{49}$ See The Radical February 1841: 21; and a reprinted article from The New York Herald, on the potential perfectibility of humankind, in The Radical May 1841: 76. Despite Evans' earlier anti-clericalism and freethinking associations, he reprinted a number of articles employing religious language.

${ }^{50}$ The Working Man's Advocate, 15 June 1844, 1. 